\title{
2 \\ The Picnic River: Pleasure Grounds and Waste Lands
}

The Georges River estuary was no rich farming site. On the contrary, along its tidal, saline length, from Liverpool to its junction with Botany Bay, the Georges River banks were mostly sandy soils, low-lying swamps with some mangroves on the water's edge or, in the downstream reaches, sandstone escarpments. ${ }^{1}$ Yet residents along the estuary frequently interacted with the broader riverine environments in ways that were highly socialised, rather than solitary. This became most evident in the 1940-70s environmental resident action campaigns, but the earlier history of the river had shaped its later developments. This river became known as a 'picnic river' - far enough away from the city to have escaped some of its worst pollution in the nineteenth century but close enough to visit - particularly once the railway lines went through. On the way to the Royal National Park, by the later years of the century, Georges River had become a destination in its own right, to which people could escape from the everyday city to picnics or pleasure grounds.

Over generations, Aboriginal people on both the northern and southern sides had found the river lands and its waters highly productive, shown by the many cooking hearths, middens and art sites along its shores. There was sustained community knowledge of the river's foods and crafts such as woven goods from its reeds, which were still being talked about to John

1 For discussion of the 'Banks and Solander Species List', see Benson and Eldershaw, 'Backdrop to Encounter'; Hunter, An Historical Journal. 
Lennis during his childhood at Herne Bay on Salt Pan Creek in the 1940s. An Indigenous horticulturalist later working with Gandangara Land Council, Lennis remembered that, for him and his family, 'the Georges River was the playground'. 2

The soils, however, were not suited to European agriculture. There were some patches of rich volcanic soils, such as Lugarno, but little intensive farming could be done on the rest of the riverbank. Instead, land use in some areas included low intensity uses like orchards or poultry farming, which meant that much of it was still considered to be underutilised and, therefore, 'wasted'. The main European clearing and intensive farming was done away from the river, on the richer, shale-derived soils where townships like Bankstown developed. Areas closer to the river were cropped for timber, contributing to erosion, while on the riverbanks themselves, there was, as discussed earlier, some use of the estuarine vegetation in the early years of British settlement, when either saltmarsh or mangroves or both were harvested and burnt for alkaline ash to make soap. The types of vegetation used and the amounts harvested were not enumerated and this early industry had declined by 1840 .

Dharawal and Dharug people along the river had posed sustained resistance to early colonisers, but they had been badly impacted by the violence of the invasion and then by the illnesses brought by the settlers. Nevertheless, people remained - like Biddy, born perhaps in the 1840s on northern Dharawal land on the southern shore of the Georges River, living and raising children on southern Dharwal land around Wollongong, but returning to the Georges River by the 1860s, marrying an Englishman, Billy Giles, and living on Mill Creek (Guragurang). Biddy became a guide for many white settlers in their fishing and hunting excursions as they travelled between the townships of Sydney and Wollongong. Their memoirs of these trips often include Biddy's teaching about her country, as well as her visits along the way to the many small Dharawal families living along the river. ${ }^{3}$

Even after the numbers of Aboriginal people on the river had been reduced, European population remained sparse. There was little interest in buying or trying to farm the marginal river lands. Yet those 'wastelands' were used vigorously, along with the river itself for fishing and swimming. Before World War I (WWI), there were three uses to which the river lands were put. There were minimally developed 'pleasure grounds' for private or

2 Lennis, interview.

3 Goodall and Cadzow, Rivers and Resilience, Ch. 4. 
commercial picnics; military training grounds and barracks; and sheltered, informal living spaces, where residents lived in huts, camps or tents. The most active commercial enterprise had developed on the river waters themselves: the cultivation of oysters. Even the 'wasteland' spaces were used productively. Rabbits and small game were hunted by settlers as well as by the Aboriginal people who still lived there, and on the swamps, ducks were hunted and birds' eggs gathered. Yet these informal uses, on which people often depended for daily food and even a small income, were not seen as 'real' farming. Even less recognised, however, were the simultaneous environmental changes that were to have a powerful impact on the political campaigns of the later twentieth century. Each of these human uses, discussed below, caused changes to the riverine bed, waters or shores.

\section{Picnics and Pleasure Grounds}

A few of these river lands were already identified as 'parks' in the later nineteenth century. The largest in the area was, of course, the national park at Audley, declared in 1879. This huge park was well known and frequented by people from the growing city of Sydney on the Harbour to the north but also by those from the large towns like Bankstown and Hurstville. ${ }^{4}$ Although the national park did not lie on the Georges River, its visitors from the city saw the Georges River as they crossed it on the railway at Como. The national park contained a wide variety of sites, which rose and fell in usage as leisure activities altered over time. ${ }^{5}$ Within it, accessible to walkers from the railway stations along the western perimeter, areas had been set aside for picnics with some 'amenities' while other areas had not been developed by Europeans in any noticeable way, allowing settlers to think of them as 'pristine'. ${ }^{6}$ This first Australian 'national' park suggested an egalitarian 'nation' made up of working people, rather than defined by affluent visitors from far away. This vision of the 'nation' as local, working people, as well as the recognition of the value of native bushland, was attractive to many on the Georges River, for whom the national park to the south became a model of the hopes they held for their own river.

4 Harper, 'The Battle for the Bush'; Harper and White, 'How National Were the First National Parks'; James, Cosmopolitan Conservationists.

5 Its beaches, for example, were far less well utilised in the nineteenth century when ocean swimming was less popular than they were by the mid-twentieth century, when ocean swimming and surfing were more popular and transport technologies were more readily available. Caroline Ford, Sydney Beaches.

6 Australian Government, Department of Agriculture, Water and the Environment, 'Royal National Park and Garawarra State Conservation Area'. 


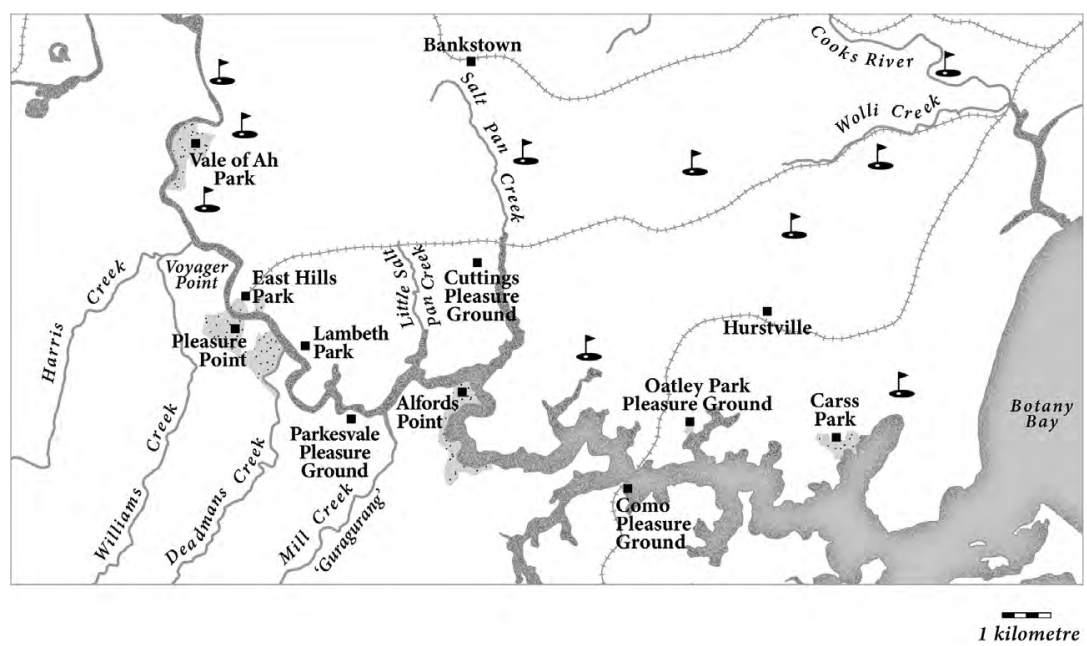

\section{Map 2.1: The Picnic River: pleasure grounds, parks and golf courses to 1950 .}

There were many parks along the Georges River, most with shops selling picnic food and hot water for tea. Those called 'Pleasure Grounds' might have additional attractions like dance floors and boats for hire. All had swimming areas, where nets protected swimmers from sharks, a very real threat in the river before pollution problems after World War II (WWII) drove the sharks away. Golf courses were rare in southern suburbs before WWII because golf was at first considered an elite sport, with most courses in the northern suburbs. The few along the Georges River were in low-lying areas, reshaped only with heavy labour. After the war, however, golf courses on the Georges River began to increase, contributing to the pressure for reclamation. ${ }^{7}$ Cartography: Sharon Harrup.

There were many smaller parklands set up on the Georges River itself, some on Crown land but much on land that had originally been granted as freehold but that had been undeveloped because it was swampy or had such poor, sandy soils. Some land near the water had been 'improved' with the addition of a toilet block and some infilling on the edges of the swampy land or a locally built jetty allowing rowboats or ferries to stop. Other sandstone lands were undeveloped in any way, whoever the owner might be, and later aerial photography showed them to be crisscrossed with tracks, which allowed everything from 'blooding' greyhounds to clandestine meetings for illicit sex.

Wherever they were located, social gatherings might range from these secret assignations to Sunday school picnics and council picnics through to family picnics. Around the turn of the century, entrepreneurs began to offer spaces for such picnics - at a price - in larger or smaller 'pleasure grounds' with more 'improvements'.

7 Molloy, A History of Padstow; Molloy, The History of Panania; Molloy, The History of Milperra; 
One park for which there is an extensive photographic record is East Hills Park, in a rich archive conserved by local resident Esme Clisby.

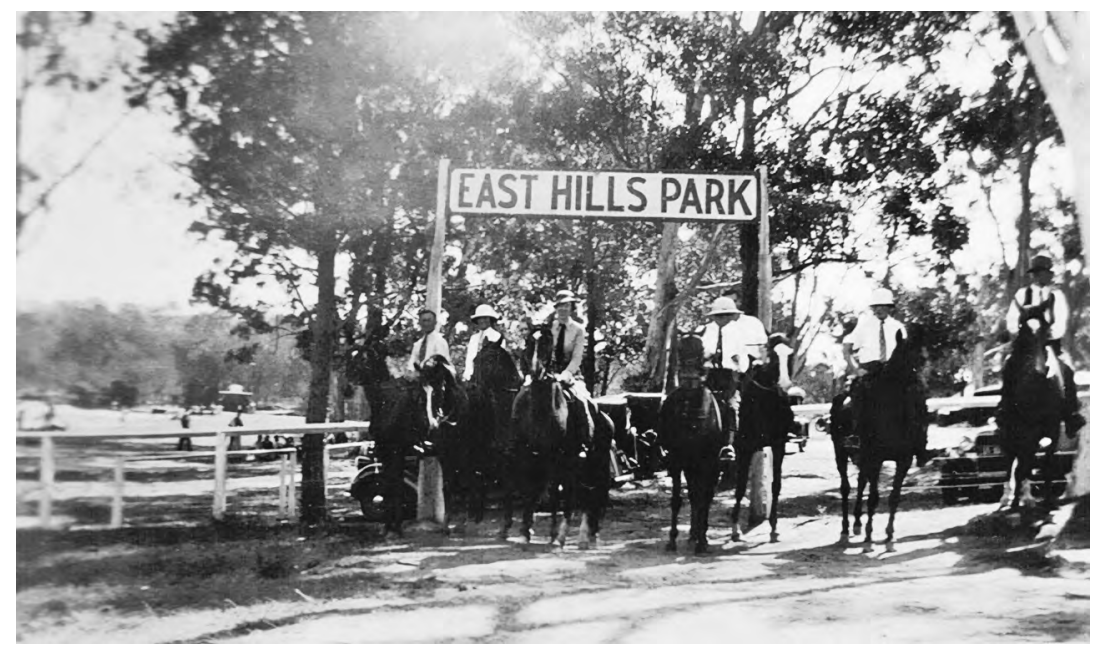

Figure 2.1: The 1920s entrance to East Hills Park.

This was marked out as a park in the earliest British land grant over the area, made to James Watson in 1838. Many people who later formed the Picnic Point Regatta Association to campaign for the national park remembered the river parks as picnic places. Esme Clisby, interviewed for this project, conserved the history of this picnic river through her archive of photographs of East Hills Park in the 1920s, many reproduced by Andrew Molloy in The History of Panania, Picnic Point and East Hills. Photograph contributed by Esme Clisby.

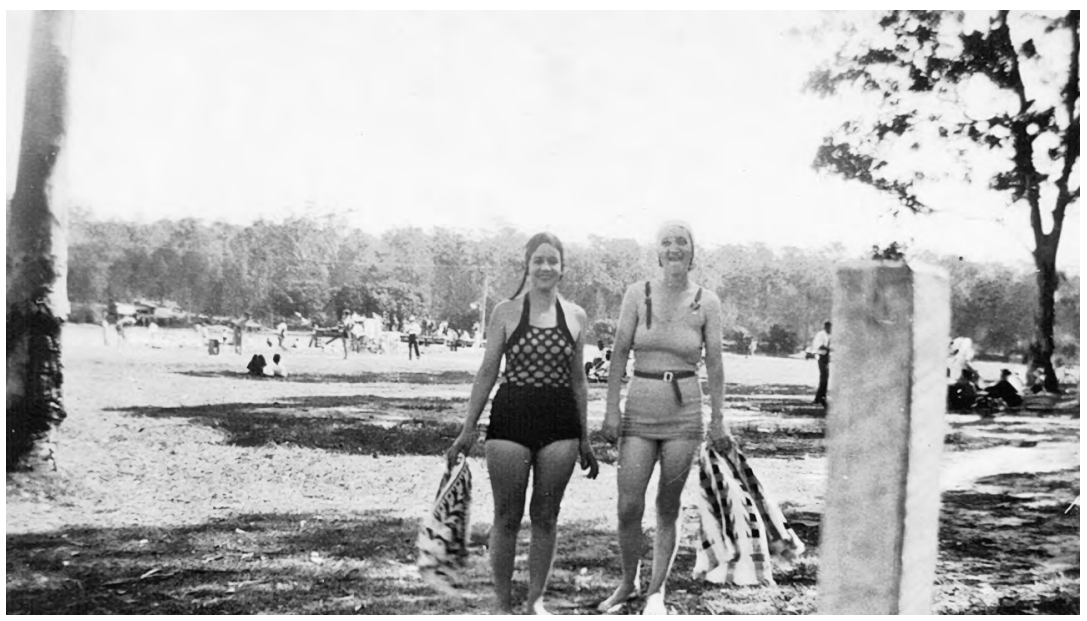

Figure 2.2: Swimmers and picnics at East Hills Park, c. 1920s.

East Hills Park was popular throughout the early twentieth century for informal picnics and swimming. The area was netted to protect swimmers from the sharks rumoured to frequent the river. Photograph contributed by Esme Clisby. 


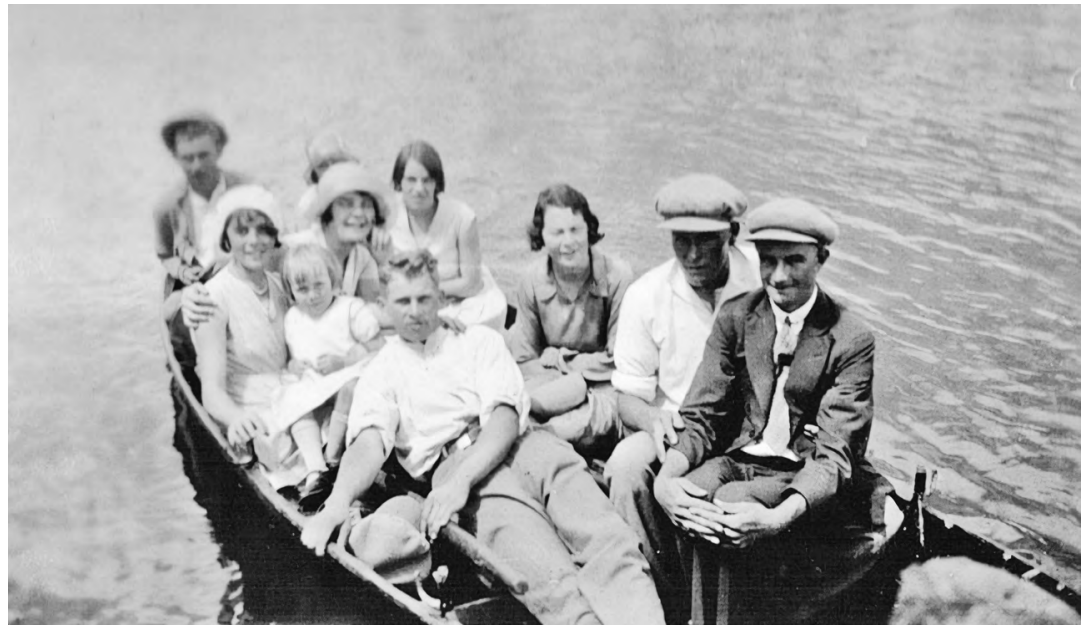

Figure 2.3: Rowboat picnic group at East Hills Park, c. 1920s.

Rowboats were commonly used along the river throughout the first half of the twentieth century for fishing, travelling and to take part in social events, like this small group coming for a picnic at East Hills. Photograph contributed by Esme Clisby.

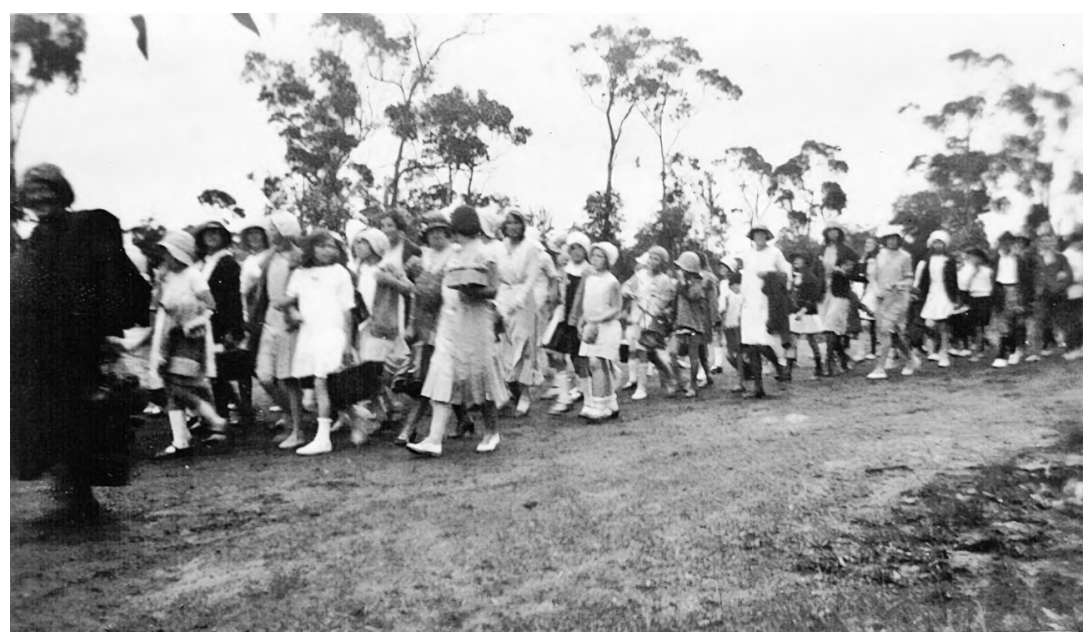

Figure 2.4: Sunday school picnics at East Hills Park, c. 1920s.

As well as informal social groups, there were often group picnics, particularly those organised by churches and Sunday schools, like this group walking into East Hills Park. Photograph contributed by Esme Clisby. 


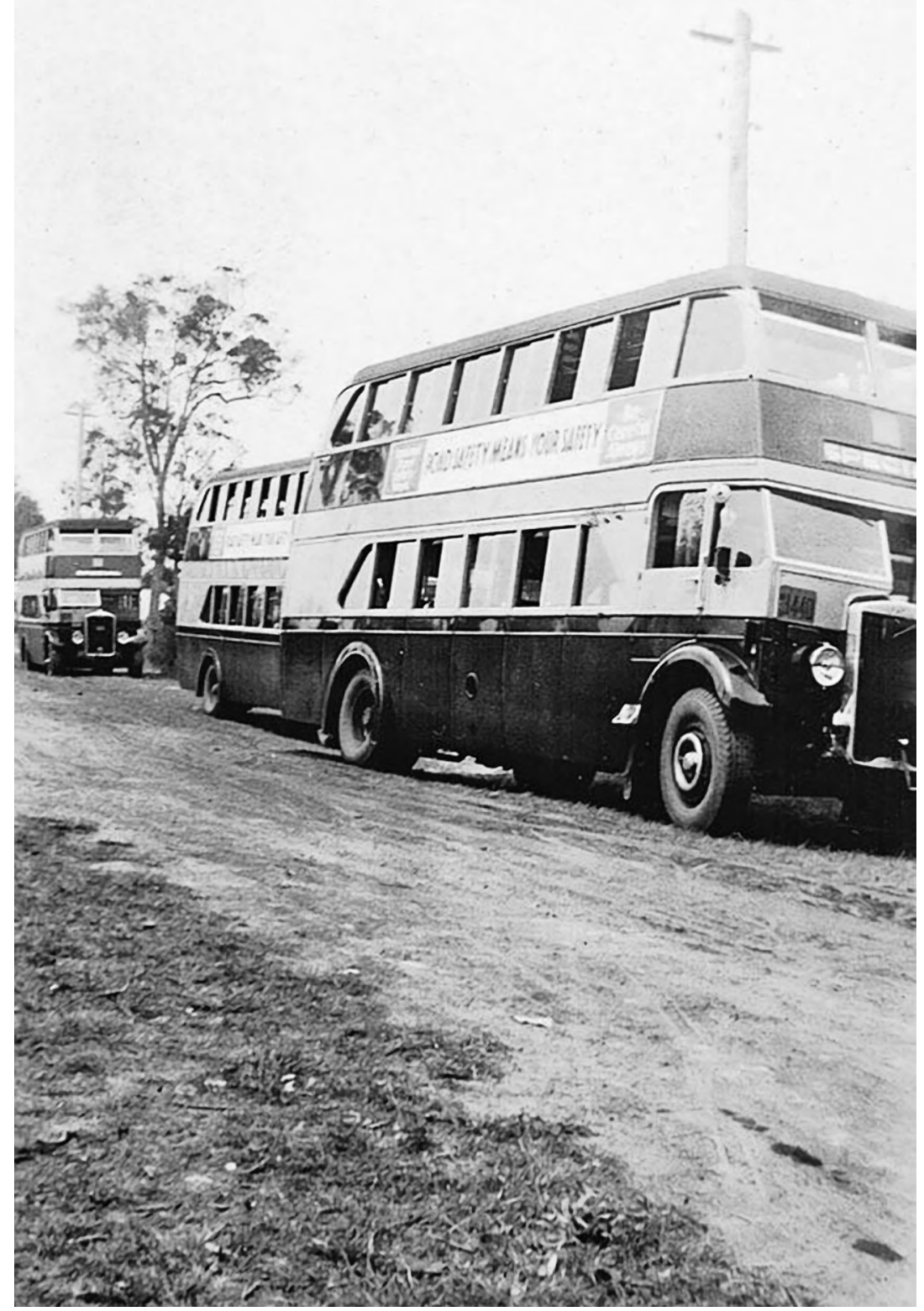

\section{Figure 2.5: Buses at East Hills Park, c. 1920s.}

Larger groups, like the Sunday school and church picnic groups, might come in chartered buses, but buses also ran from the railway stations at Bankstown and other larger townships, bringing visitors from the inner city out to the picnic river. Photograph contributed by Esme Clisby. 


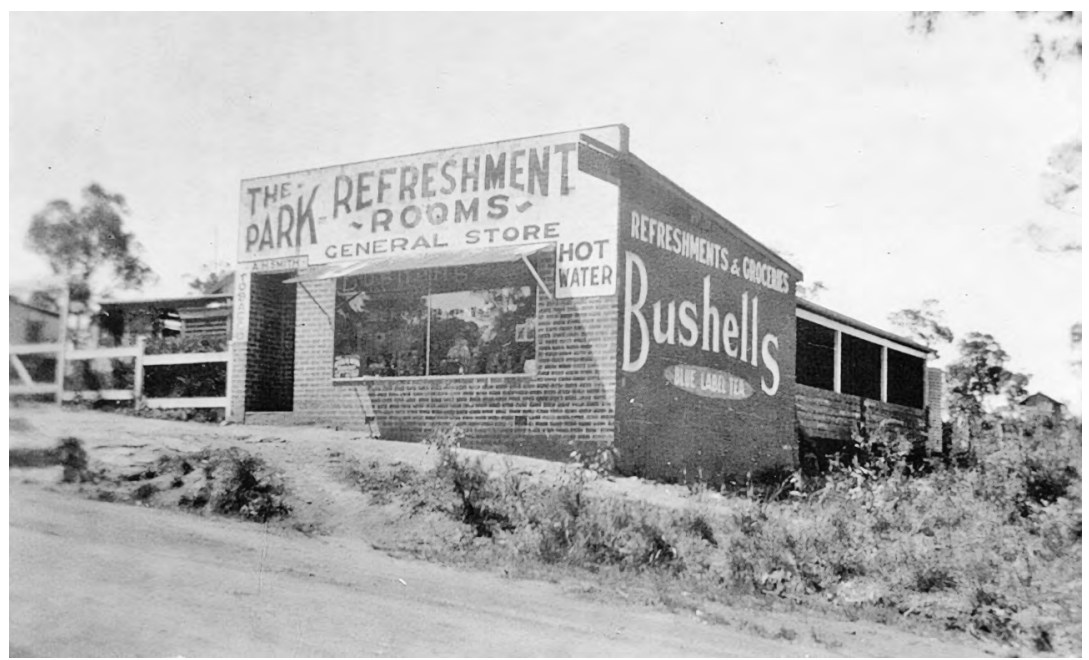

Figure 2.6: Refreshments at East Hills Park, c. 1920s.

The refreshments were basic - hot water for tea and freshly made sandwiches and cakes from the shop on the hill above the picnic ground, which also sold groceries for the scattered houses among the bush at East Hills. Photograph contributed by Esme Clisby.

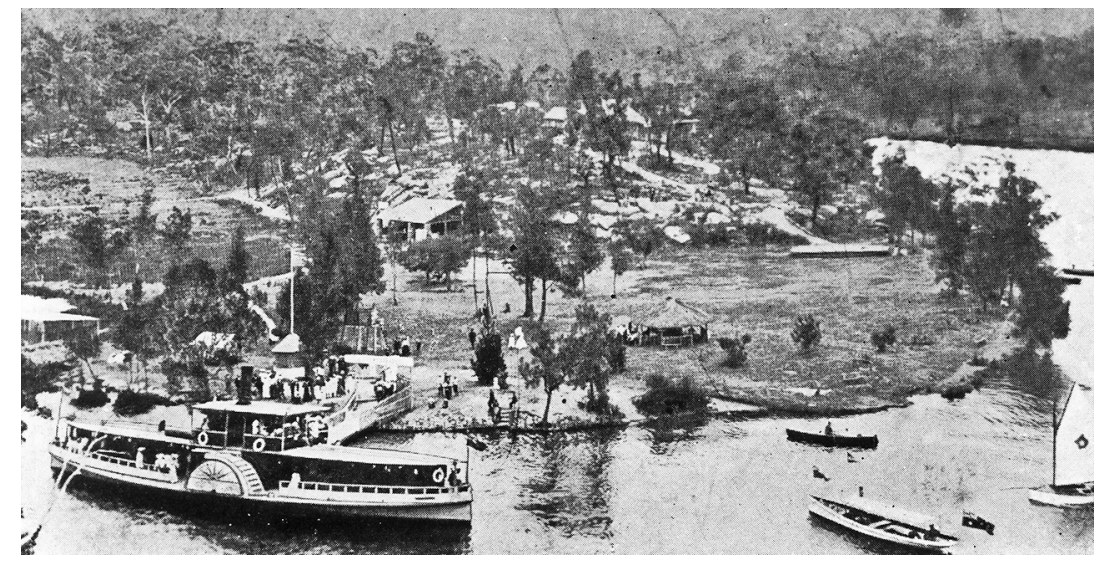

Figure 2.7: Parkesvale, 1906.

Parkesvale - named after Sir Henry Parkes - was much more grand. At 50 acres, this highly publicised commercial pleasure ground on the Sutherland side of the river advertised itself as 'The Ideal Holiday and Tourist Resort'. It offered not only camp sites and a speedy motor launch to ferry visitors from the railway station at Como, but also 'boating, fishing, dancing, bathing, swings, merry-go-rounds' and even a 'razzle-dazzle'. As well, 'genuine travellers' - those who had travelled from the inner city - could consume alcohol along with their other activities. Photograph courtesy of Bankstown Historical Society. 
Access to transport was a crucial factor in the siting of such pleasure grounds, as it was in choices about land purchases. Train lines, like that near Como, allowed the movement of crowds from the inner city to the Georges River, and subdivisions in the 1920s were often motivated by new railway building - or by rumours of future construction! From the railway stations, buses as well as boats and ferries would transport picnickers to the pleasure grounds, reflecting the common use of watercraft for everyday transport as well as for fishing, competition or leisure.

The best known was Parkesvale, upstream from Alfords Point on the southern, Sutherland side of the river, opening in 1905, which could be reached by paddle steamer (see Figure 2.7). The Como Pleasure Ground, close to the railway line, had opened earlier, in 1895, while Oatley Park was earlier still, in 1887. As the advertisements for Parkesvale suggest, pleasure grounds catered for all ages and offered many different types of pleasures, from razzle-dazzles to boating to dancing. ${ }^{8}$ What made such establishments on the Georges River so attractive as Sunday picnic sites for city dwellers was that alcohol could be purchased there for 'genuine travellers', while the dance floors at Parkesvale and other pleasure grounds were used for local social gatherings as well as for people from further away. ${ }^{9}$

These larger pleasure grounds had mostly fallen into disuse by WWI, but there were smaller picnic grounds that continued to operate until WWII, shown in Figures 2.8-2.12. Some, like Carss Park, set up in 1924 on Kogarah Bay, and Sans Souci on Botany Bay, continue to exist as parklands, with just tiny kiosks as a reminder of their former glory.

Whether large or small, these pleasure grounds made their money from selling cakes, tea and alcohol, and by renting out rowing boats and dance halls. Later still, some swamp areas were 'improved' again to become golf courses: filling in a bit more of the swamp to create landscaped fairways and greens allowed groups of people to play this social and competitive sport. Golf courses, although they offered trees and greenery, brought their own problems. The greens and fairways needed fertilisers that washed into the creeks and rivers, acting as a contaminant and nutrient that encouraged troublesome growths like algal blooms. The course also

8 A 'razzle-dazzle' was a common and popular piece of circular play equipment in Australian children's parks in the early twentieth century. Although seldom seen more recently because it was believed to be dangerous, it was popular precisely because of the speed that could be achieved as it was pushed by children riding or running alongside. Larger versions, like that at Parkesvale, were suspended from a central pole.

9 Elliott Goodacre, interview. Elliott, a Picnic Point resident when interviewed in 2002, recalled his father's accounts of his youth along the Georges River. Earnshaw, The Land Between Two Rivers, gives vivid accounts of the pleasure grounds at Oatley and Carss parks. 
needed frequent watering, particularly through hot and dry summers, and the water itself contributed to altered watertables beneath the course, as well as aiding the flow of fertilisers into the natural waterways. ${ }^{10}$

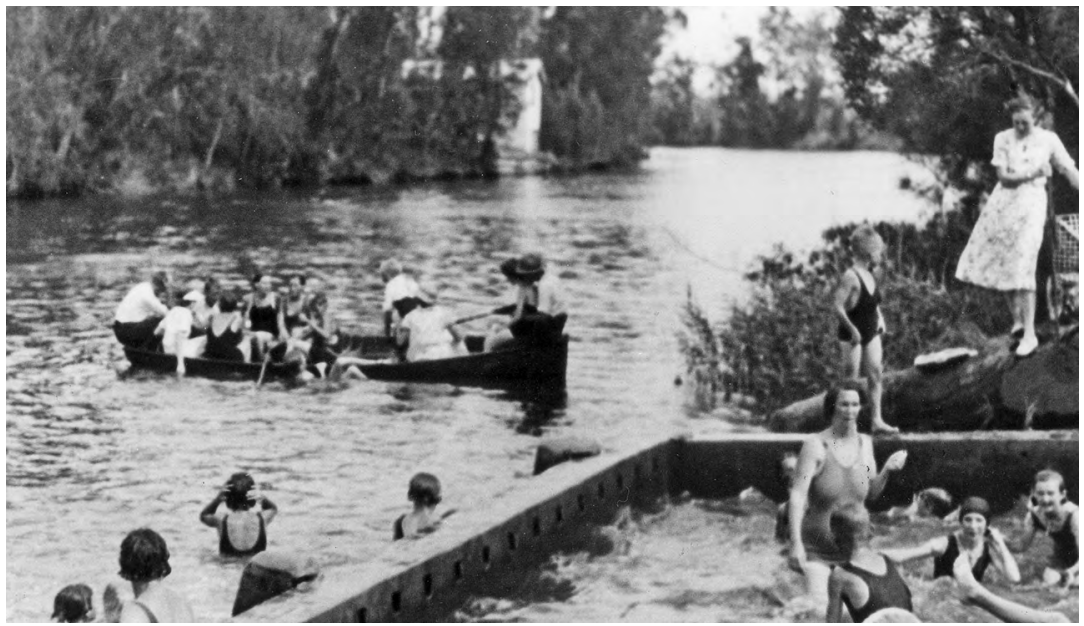

Figure 2.8: Hollywood Park on Prospect Creek, north of Milperra, c. 1920s.

This was one of many small parks along the river known as 'pleasure ground' with netted baths and hired boats. Photograph courtesy of Bankstown Historical Society.

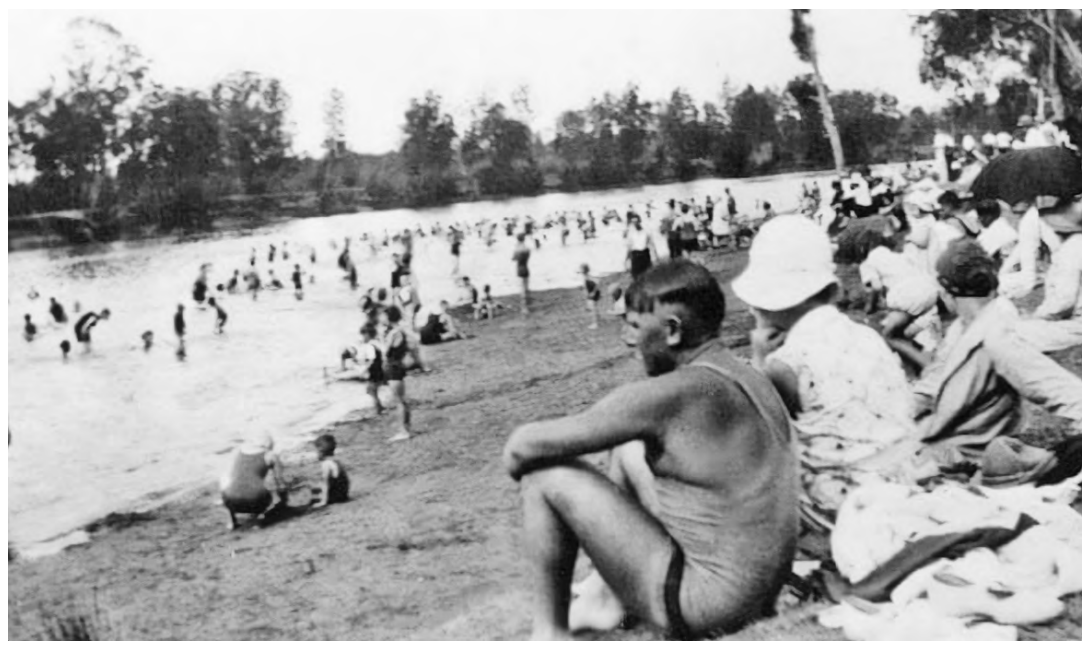

Figure 2.9: The Vale of Ah Park, c. 1920s.

Another popular park with large netted baths, just downstream from Milperra and close to Kelso Swamp. Photograph courtesy of Bankstown Historical Society. 


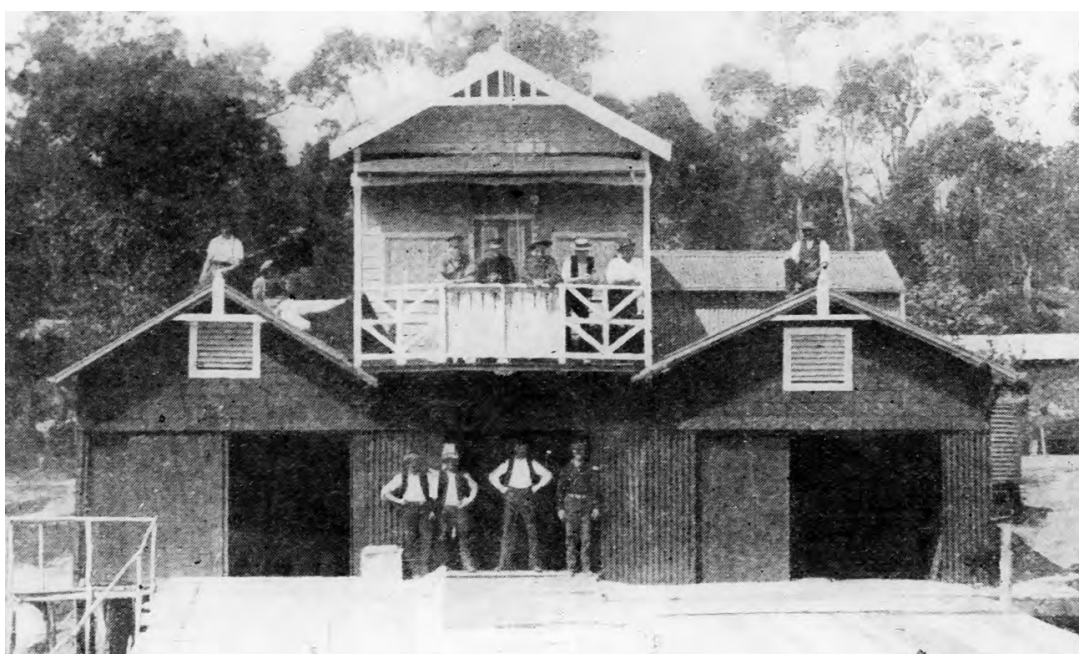

Figure 2.10: Lambeth Street Wharf Pleasure Grounds, c. 1920s.

Another substantial commercial holiday and 'pleasure ground' was at Lambeth Street Park, downstream from East Hills and opposite what is now Sandy Point. Visitors arrived on buses from Bankstown station and could stay in sturdy cabins built on site. Photograph courtesy of Bankstown Historical Society.

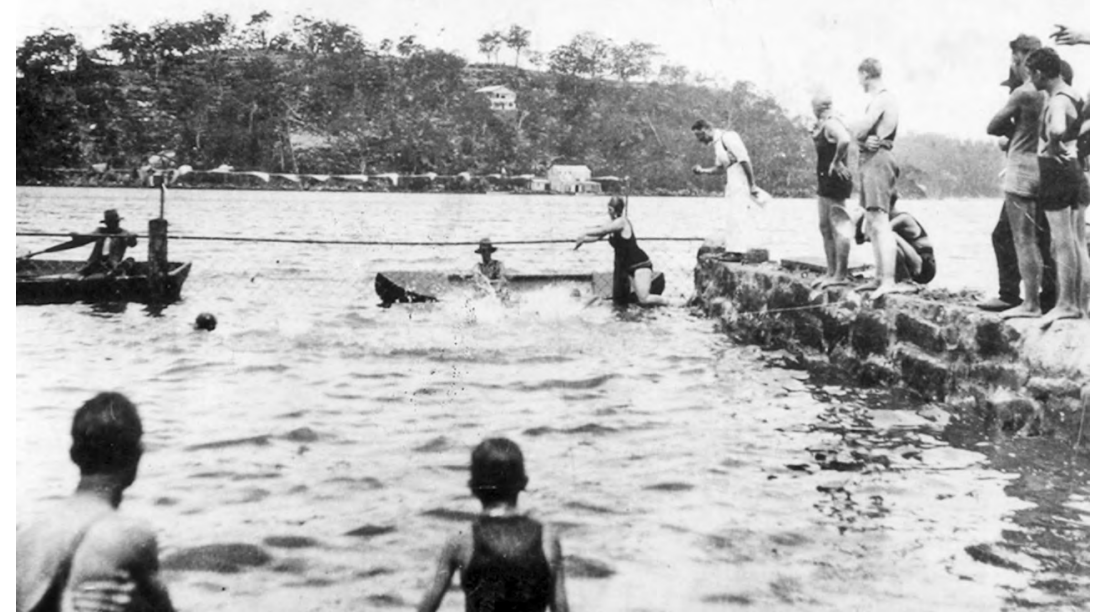

Figure 2.11: Lessons at the Oatley Pleasure Grounds pool, 1928.

In the lower estuary there were more pleasure grounds. The largest was Como Pleasure Grounds, on the southern shore, with a grand building on a promontory visible from the railway line crossing the Georges River. Across the river in the Hurstville area was Oatley Pleasure Grounds, on the western side of Oatley Bay, and here too was a safely netted swimming pool and swimming lessons were held regularly. Photograph courtesy of Oatley Amateur Swimming Club and the Dictionary of Sydney. 


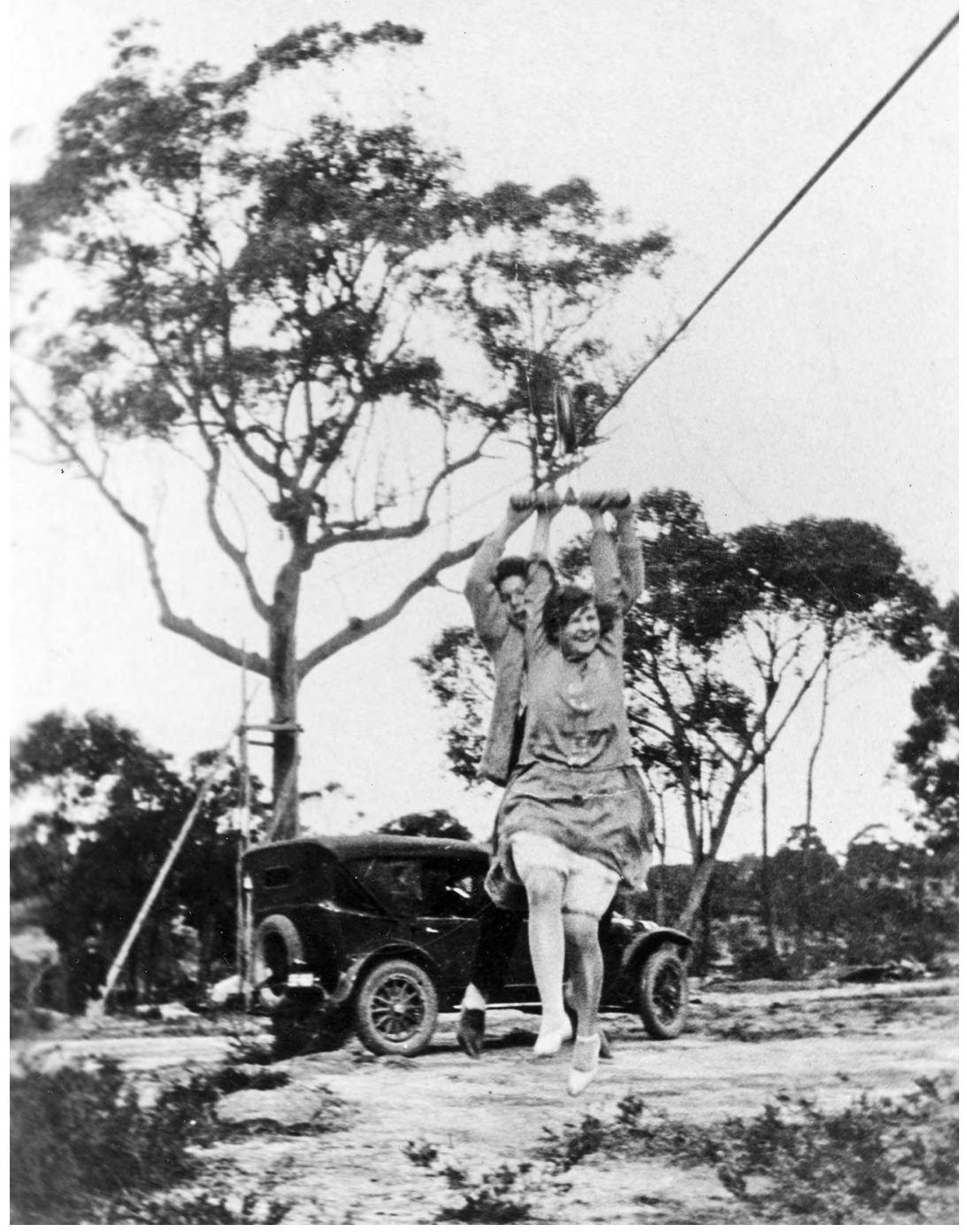

Figure 2.12: Flying fox at Cuttings Pleasure Ground on Salt Pan Creek, c. 1920 s.

All of these smaller pleasure grounds offered netted pools, picnic grounds and a shop, and most had playgrounds - just for fun - like the razzle-dazzle at Parkesvale and this flying fox at Cuttings Pleasure Ground on Salt Pan Creek. Photograph courtesy of Bankstown Historical Society. 
Even before the golf courses, local councils had established rubbish tips in a few of these low-lying areas, which eventually allowed them to be covered over to be grassed and made into picnic grounds and a few into playing fields, like the Kelso Swamp area near the Vale of Ah (see Chapter 7). A similar attempt was made with Renown Park on the west arm of Oatley Bay but, as we shall discuss in Chapter 12, this 'reclamation' failed and the surface of the 'park' remained so unstable and toxic that much could not be used. Such 'reclaimings' were, however, occurring only at a modest pace and, as late as the 1950s, swamps were characteristic elements of the landscape around people's homes and remain so in people's memories. ${ }^{11}$ Kevin Jacobsen (born 1934) is one for whom the swamps around East Hills still hold a place in childhood memory:

We used to play there. The swamp's not there anymore - but we used to skate on the mud on the swamp. And we'd catch little swamp things. And we used to go rabbiting too. ${ }^{12}$

Such sociality 'beyond the fence lines' continued along the river despite the increasing subdivision of farming blocks from the 1920s in anticipation of the railway. Sociality, picnics - whether commercial, church or family - fishing and other leisure activities 'enculturated' the open spaces as highly valued elements of the identity of these working-class areas and the residents who lived in them. The types of sociality were shaped by historical periods and norms. Multi-generational family picnics or fishing expeditions were common among Anglo-Irish local residents in the 1920s and 1930s, but there were also picnics organised by church fellowships or Sunday schools. After WWII, picnics might be organised by the companies that owned the new large factories sited along the river, assembling 'modern' electric white goods, and seeking to foster corporate loyalty and bonding among employees. So while the householding communities of the Georges River were, by the 1960s, 'suburban' in the sense of valuing private and freestanding house blocks, on which they may have their own gardens, they did not see this as isolating them from the local, public and 'wild' spaces of the area's riverbanks or from the water of the river itself.

Nor was Indigenous sociality a thing of the past: Aboriginal people continued to live in secluded areas along the Georges River, with longestablished Indigenous communities on Prospect, Harris and Williams creeks valuing the social networks they offered as they continued to fish,

11 PPRA, interview, 22 March 2006.

12 Kevin, Colin and Carol Jacobsen, interview, 12 July 2006. 
prawn and share meals together. Denis Foley's grandmother, for example, had grown up and been living on Prospect Creek for many years, upstream of its junction with the Georges River at Chipping Norton. ${ }^{13}$

After Biddy Giles returned to the Georges River in the 1860s, one of her daughters, Ellen, followed her, only to be forced by the New South Wales Aborigines Protection Board in 1883 to go to Cummeragunja Station on the Murray River. Ellen married Hughie Anderson there, a Yorta Yorta man, and they returned to the Georges River in the 1920s, purchasing a block of land on the eastern side of Salt Pan Creek. Ellen was herself to have a role in the shaping of the floral symbolism of Australian nationalism. Her knowledge of Dharawal environments was drawn on by C. W. Peck in his long (fruitless) campaign to have the waratah replace the wattle as the national icon. ${ }^{14}$

Ellen and Hughie were joined there by William Rowley, who had been born around the mid-nineteenth century at Pelican Point on the promontory known as Towra Point, where the Georges River flows into Botany Bay. After working for some time as the overseer at Thomas Holt's oyster farm at Sylvania, and living and marrying at La Perouse, Rowley had moved upstream too in the 1920s, purchasing the block next to Ellen and Hughie on Salt Pan Creek. ${ }^{15}$

The Anderson and Rowley families each formed the hub of extended family and visitor camps on these blocks. ${ }^{16}$ By this time, along with the Anderson and Rowley families at Salt Pan Creek, there were welldocumented Aboriginal communities living on Prospect Creek near Chipping Norton, on Williams Creek, at Voyager Point on Mill Creek and at Kogarah Bay, along with many other small family groups along the riverbanks and islands, as well as in a number of encampments around Botany Bay itself. ${ }^{17}$ The Salt Pan Creek community - the Anderson and Rowley families and many visitors - lived there during the Depression, and a number of people have remembered their times there fishing and prawning together in the creek below the blocks. ${ }^{18}$

13 Foley, Repossession of Our Spirit; Gapps, Cabrogal to Fairfield City.

14 Goodall and Cadzow, Rivers and Resilience, 133, fn. 43.

15 McKenzie and Stephen, 'La Perouse'.

16 Goodall and Cadzow, Rivers and Resilience, Ch. 6; Irish, Hidden in Plain View.

17 Foley, Repossession of Our Spirit; Gapps, Cabrogal to Fairfield City; Goodall and Cadzow, Rivers and Resilience; Foley and Read, What the Colonists Never Knew.

18 Campbell and Thomas, interview, 24 September 1980; Campbell, interview, 14 July 1982. 


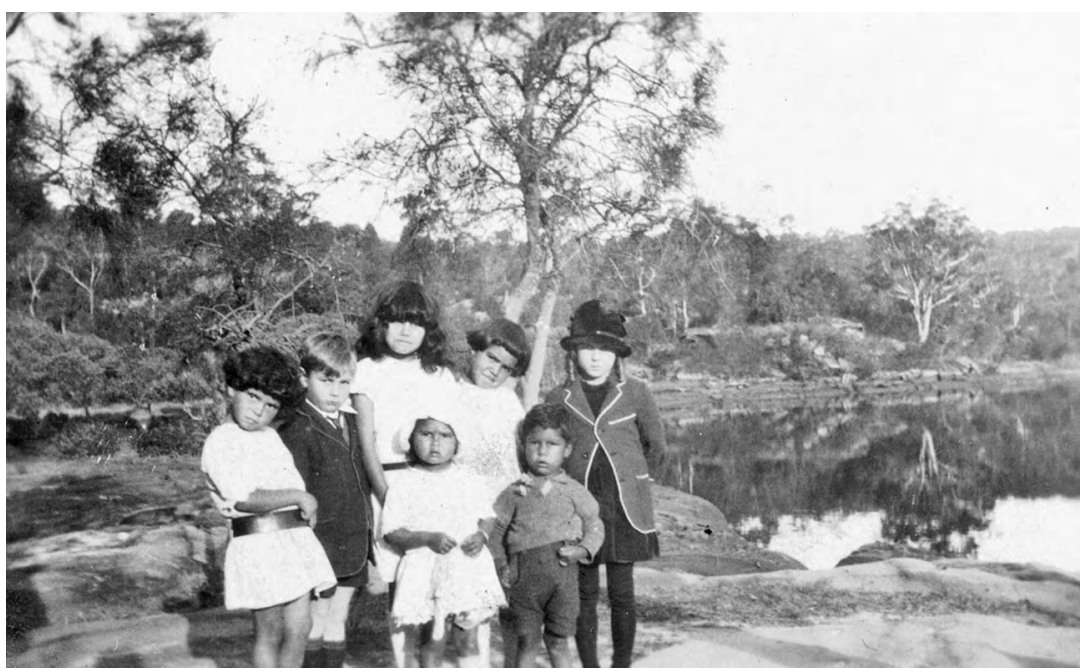

Figure 2.13: Younger members of Anderson family, Salt Pan Creek, 1925.

Younger members of Ellen and Hughie Anderson's family, two of their grandchildren, Ellen and Tom Williams (Jnr) (the two youngest children, centre), on the shores of Salt Pan Creek, c. 1925. Courtesy of State Library of New South Wales. Source: PXA 773/Box 1, Series 03 Box 1: Australian Indigenous Ministries pictorial material: pre-1960 photographs, part 2, item 78 .

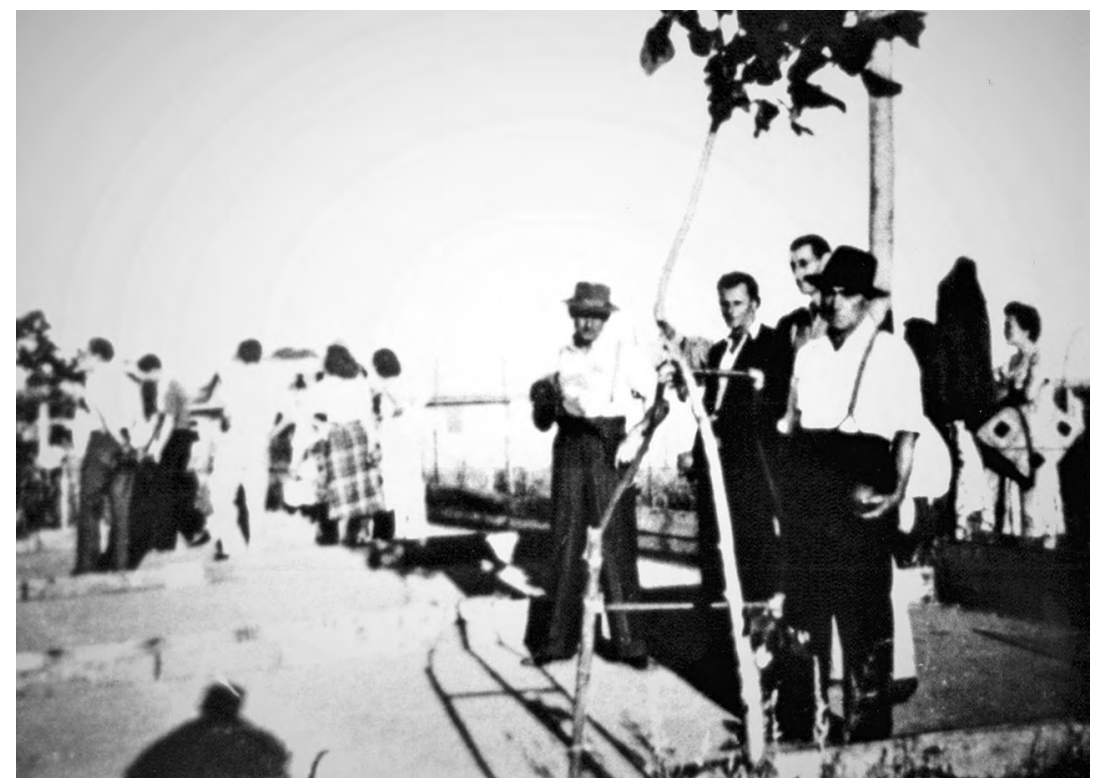

Figure 2.14: Bocce at Horsley Park, 1952.

A game of bocce being hosted by the Crestani family at their home at Horsley Park around 1952. Photograph courtesy of Fairfield City Library and Museum Photographic Collection. 
The very public picnicking of British and Irish settlers along the Georges River paralleled the social gatherings of Italian or German settlers taking place at the same time, although these tended to be occurring in more private spaces, like homes and market gardens that remained at a greater distance from the river. Members of the Italian community, like the Italian workers who tended the grape vines on Williams Creek and at Fairfield in the 1880s, used the market garden spaces they rented to have bocce games, while families in the 1950s, like the Crestanis at Horsley Park, hosted community gatherings at their home. ${ }^{19}$ The Germans at Lugarno and Holsworthy had social musical gatherings, playing zither and guitars, in the spaces of private homes, rented or owned, in the $1910 \mathrm{~s} .{ }^{20}$ So although the most public sociality along the river was in the gathering of AngloCeltic settlers in parks and picnic grounds, the many remaining spaces and interstices along the river - the 'wastelands' - meant that there were other less visible social events taking place in less public settings.

\section{Soldiers and Swamps}

A proportion of these 'wastelands' served military purposes. Military training grounds had been established in 1899 at Artillery Hill near Grey's Point within the 1879 national park at Sutherland. Then, in 1912, the federal government established the large Holsworthy training facility, compulsorily acquiring grape farms along Williams Creek (where Aboriginal farm owners and Italian vine workers had been living) and other farmed land as well as unused spaces across a large area right up to the southern shore of the Georges River.

The military role was expanded during WWI with an internment camp as well as increased training facilities for Australian troops. ${ }^{21}$

19 Gapps, Cabrogal to Fairfield City, 293, 342-45.

20 Blewett, Ferries and Farms.

21 McKillop, 'The Royal National Park Line'. 


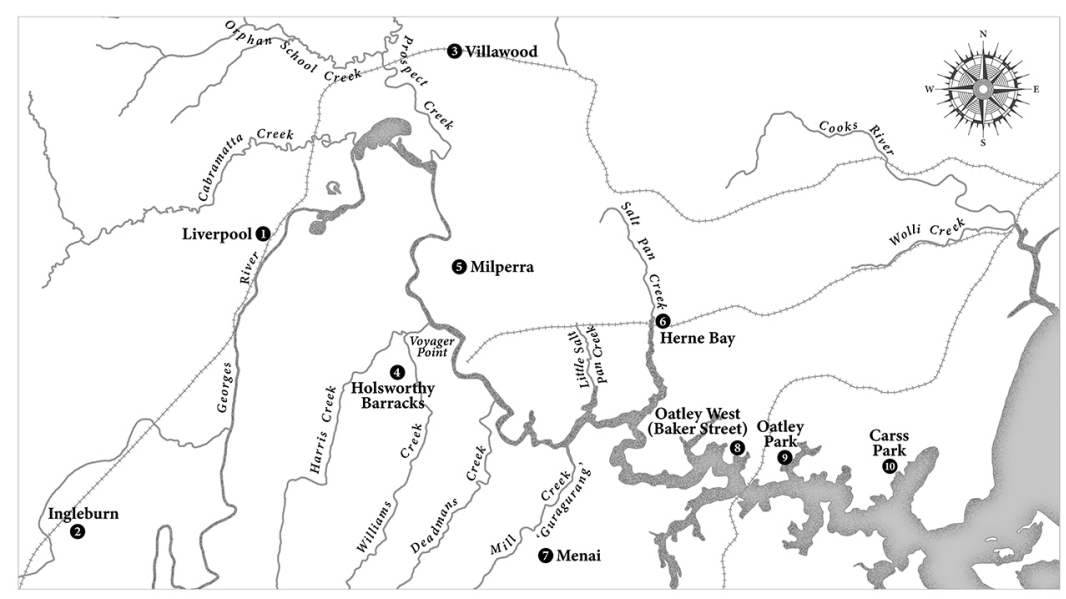

(1) Liverpool

Internment Camp from 1939

Extended for 17th Australian Camp Hospital, Australian Army.

(2) Ingleburn 16th, 68th and 72nd Australian Camp Hospital, Australian Army. Training Camp from 1940.

3 Leightonfield Munitions Factory previously called Villawood Munitions Factory, 1941.

(4) Holsworthy Detention Barracks Training, from 1912. Detention Barracks, WWI \& WWII.

(5) Milperra

Soldier Settlement 1917
6 Herne Bay

1 kilometre

General Hospital, USASOS, 1942

(7) Menai

Lucas Heights HIFAR reactor 'Critical' (turned on) in 1958.

8 Baker Street Oatley West Oatley Anti-aircraft Searchlight Unit Camp.

9) Oatley Park

Tasmanian Battalion campsite Campsite and training area for 26 Field Company Royal Australian Engineers (RAE).

10 Carss Park

1 Division, 26 Field Company RAE used the Ambulance Room of the St George and Sutherland
Ambulance as an Orderly Room during WWII.

\section{Map 2.2: Locations of military sites along the Georges River.}

This map indicates the impact of WWII on the Georges River. Older military sites like Holsworthy expanded while new military installations proliferated, often built on low lying areas and usually discharging sewage and other waste directly into the river. Cartography: Sharon Harrup.

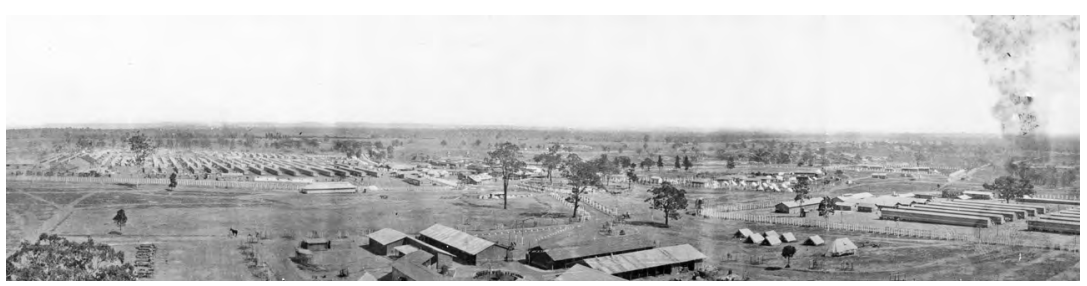

\section{Figure 2.15: Panorama view of Holsworthy military camp and training} ground, 1914-18.

As a major training ground and barracks for Australia's military until after WWII, Holsworthy remained a secretive and mysterious place to local residents who were not allowed entry. Set aside first in the 1880s, this military site covered 50 acres by the early twentieth century. Photograph reference number: H02147-1. Reproduced courtesy of Australian War Memorial. 


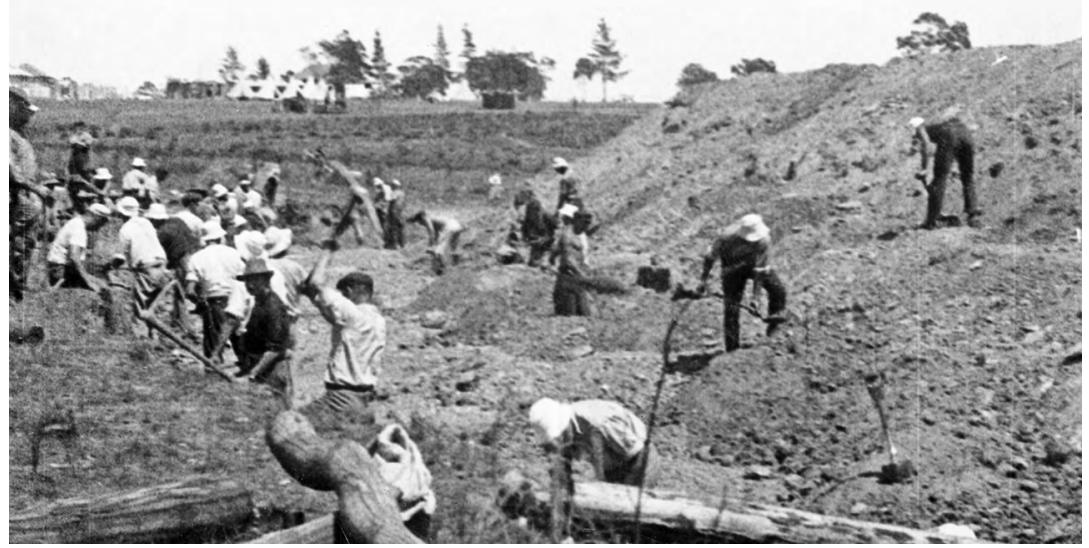

Figure 2.16: German internees in 1916 on pick and shovel work.

During WWI and WWII, Holsworthy not only held captured enemy troops but also naturalised Australian citizens originally from countries then at war with Australia and Australian-born citizens whose ancestors had migrated from enemy countries like Germany and Italy.22 Photograph reference number: H17640-2. Reproduced courtesy of Australian War Memorial.

Even before that war ended, lands near Milperra became soldier settlement cooperative allotments from August 1917, planned to be poultry farms. The intensive clearing needed was impossible for many recipients, who had been selected to compensate them for wounds sustained in the war. ${ }^{23}$ Most of the original returned servicemen had left the settlement by the later 1920s, leaving much of this land unused again.

Once again, in WWII, lands labelled as 'unused' along the Georges River were taken up for military camps, training grounds and more internment and prisoner of war jails. In 1943 these sites were extended even further to accommodate US troops who retreated to Australia during the Pacific War. Bushland, golf courses and pleasure grounds were all erased by

22 National Archives of Australia, 'Wartime Internment Camps in Australia', accessed 11 January 2021, www.naa.gov.au/explore-collection/immigration-and-citizenship/wartime-internment-campsaustralia.

23 Much soldier settlement analysis is based on Victorian settlements. Glenys Allison has undertaken detailed research in the New South Wales Closer Settlement and Soldier Settlement files. See Allison, 'Bankstown Soldier Settlement Milperra'. 
military camps and army hospitals. The largest was at Herne Bay near Salt Pan Creek, where a huge US Army hospital was built in 1943 on a golf course previously 'reclaimed' from saltmarsh swamp in the 1930s - with much heavy labour - by the Levingston family. ${ }^{24}$

Later in the twentieth century there would be further impacts of warfare and military personnel, technologies and experiences on the Georges River that negatively affected environmental conditions. Military technology, emerging in the 1930s and expanding during WWII, was to shape the way the changes in the more-than-human world of the river were seen.

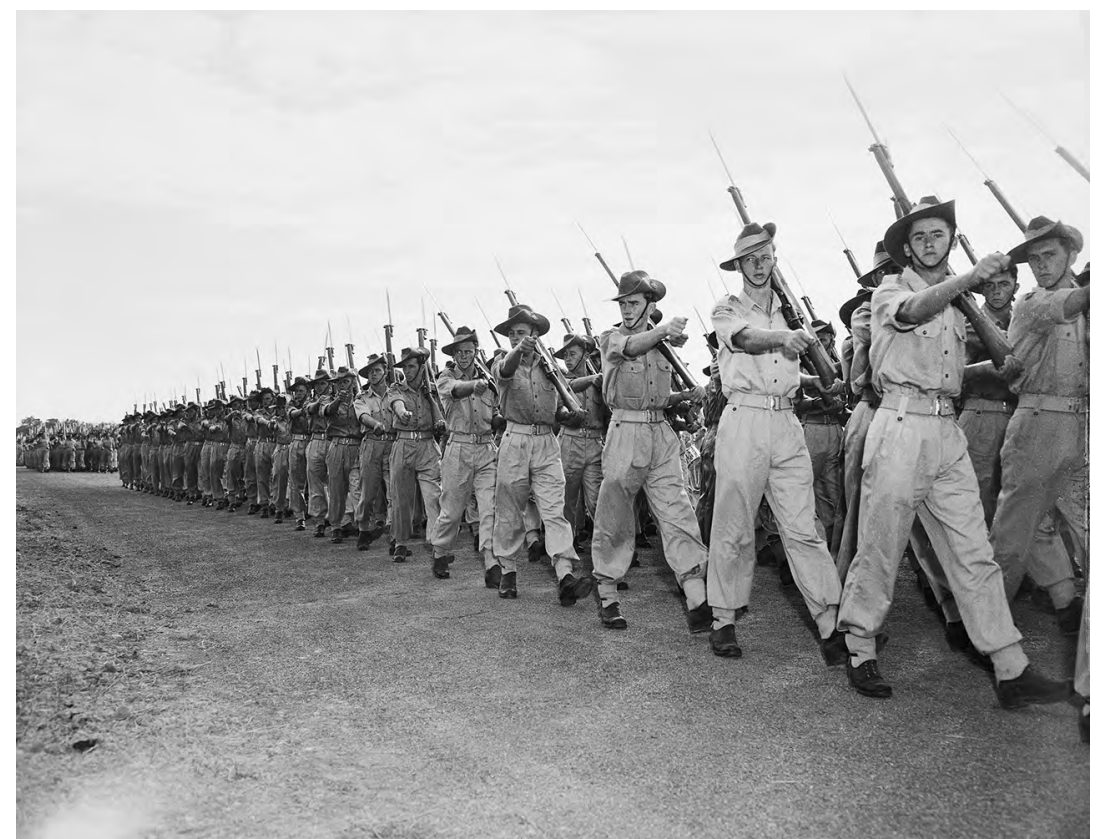

Figure 2.17: National servicemen march past at their passing out parade at Holsworthy, 1954.

Young men undertaking their compulsory period of national service-known as 'conscription', 'nasho' or, in the later American term, 'the draft' - were trained for part of their service time at Holsworthy. So, although a restricted and mysterious place, Holsworthy was a constant reminder for young men in the area that their time might come. Photograph reference number: DUN/54/0257/EC-2. Reproduced courtesy of Australian War Memorial.

24 Madden, Hernia Bay; US National Library of Medicine, 'Collections', accessed 11 January 2021, collections.nlm.nih.gov/. 


\section{Farming the Water: Oysters and Growers}

Settlers slowly began to value oysters for eating, not just for burning their shells for lime. Oysters were abundant, so early settlers could simply harvest naturally growing shellfish on the rocky shores along the Georges River. Thomas Holt attempted unsuccessfully to cultivate oysters during the 1860s, but more successful farming began on the Georges River during the 1870 s, initially by dredging in mud near the shores and, by 1900 , by catching oyster spawn (spat) on mangrove sticks, initially from the Georges River and later from south coast areas like the Minnamurra River. The young oysters were laid out in netted trays or racks where they would fatten until eventually gathered for market, either unshelled or in bottles. 25

The oyster farming families lived locally, forming part of the slowly growing communities along the shorelines. Many members of the oyster farming Drake and Derwent families, for example, lived in Wyong Street, which ran down to Neverfail Bay, between Gungah Bay and Oatley Bay. Members of the family lived on this street or nearby for all of the twentieth century and into the twenty-first. Tending the maturing oysters in their trays in the bays and then preparing the harvested oysters for market was labour-intensive work. The industry produced a luxury gourmet product, and yet these remained small family concerns, drawing largely on family labour and producing only a modest return. Until the 1980s, as will be discussed below, the industry required high levels of environmental knowledge about the estuary and surrounding coastal areas but produced little surplus capital to enable advanced technical or scientific support.

In the early years of the twentieth century, oysters were cultivated in Lime Kiln Bay and other areas between Lugarno and Oatley Bay, but by the 1930s many farms had moved down river, setting up trays in Gwawley Bay and in the Woronora River, closer to the junction of the Georges with Botany Bay. However, Neverfail Bay remained an important base for the industry; it was close to the areas where the farming families continued to live, so their equipment was stored in sheds and their punts and other vessels were moored there.

25 Jackson and Forbes, 'Oysters on the Georges River'; Nell, 'The History of Oyster Farming'. 
Oyster farmers were in a very specialised industry - they were farming the waters of the Georges River - so their industry was sensitive, and particularly vulnerable, to changes in the water quality, an issue that was to rise in urgency in the period discussed in later chapters. Yet, at the same time, oyster farmers and their extended families were all local residents in the suburbs along the river, and were interested in, and sometimes very actively involved in, campaigns about environmental issues on land like reclamations and dumping of garbage and dredged material, as well as about water quality.

\section{Hopes and Disappointments}

Before WWI, the building of railway lines seemed to offer the hope of economic expansion as had occurred in the UK and the US. Yet in Australia the population was simply not large enough to allow rapid expansion simply because there were whispers of a line. This proved to be the case during the 1920s, when hopes for a railway extension from Kingsgrove to East Hills through the Georges River area led to extensive subdivisions. The line eventually opened - with one track only - in 1931. Alas for the land developers, by then the Depression had hit and the blocks for which they had hoped to gain enormous profits lay pegged out but unpurchased. Peter Spearritt estimates that the amount of subdivided land in the Bankstown municipality more than trebled during the decade of the 1920s, at a time when the number of occupied properties in the area barely doubled, while in the adjacent easterly municipality of Canterbury, the number of occupied properties actually fell, years before the Depression hit. ${ }^{26}$

Nevertheless, the overcrowding in inner-city areas was already urgent by the end of WWI. An attempt to address the problem had been made with the establishment of a Government Housing Commission, in existence from 1919 to 1924 , until it was abruptly dismantled by a conservative government. ${ }^{27}$ Overcrowding only became worse during the 1920 s and then the Depression interrupted any building at all. Dr J. S. Purdy, Sydney's metropolitan medical officer, pointed out as early as 1920 that the alarming rates of severe inner-city overcrowding were a major health

26 Spearritt, Sydney's Century, 50-52. The final extension from East Hills did not happen till 1987! 
hazard. ${ }^{28}$ Yet even with the failure of speculative subdivision towards the river, the population of the Bankstown areas closest to existing stations rose through the decade. In fact, Canterbury and Bankstown had the greatest proportional increase in population across the city. ${ }^{29}$ So the expectation of future increased building expansion in the Georges River were clear. Dr Purdy was extremely critical of the area, pointing out in 1924 that Bankstown had reserved less than 10 per cent of its area for parks and recreation. He foresaw that the area would fall 'into the condition of the older portions of the city' unless it purchased land 'on the periphery as playing areas in advance of population. ${ }^{30}$

\section{Depression Camps}

The military presence on the river lands still left much unused and apparently 'wasted' space, particularly along the uneven, steep or boggy riverbanks. This land was needed in the economic depression of the 1930s, when many workers were made homeless by unemployment, evictions and foreclosures. Areas with high proportions of working-class residents like Bankstown were particularly hard hit and there were many battles over evictions, reflecting the active network of political organisations even if, as Nadia Wheatley has pointed out, they could offer few long-term solutions. $^{31}$

Andrew Molloy has gathered many oral histories of the unemployment camps. For example, Ray Parker, a delivery boy from the butchers at Padstow, remembered the 'Happy Valley' where:

About 8 families lived in mostly bag humpies ... they were good men - many who had never been out of work in their lives before, but who had just fallen on tough times like so many people. ${ }^{32}$

Other memories were much more grim. Molloy's interviewees recalled families damaged by poverty, isolation and ill health, then scarred by domestic violence. These camps made few calls on the riverbank

28 Purdy, 'Metropolitan Health Officer's Report for 1920', 45; 'Housing Problem', Daily Telegraph, 7 October 1920, 6.

29 Spearritt, Sydney's Century, 38.

30 Purdy, 'Metropolitan Health Officer's Report, 1924', 112; 'More Parks: Dr Purdy's Plea', Daily Telegraph,14 April 1925, 5.

31 Wheatley, 'Meeting Them at the Door'.

32 Molloy, A History of Padstow, 99. 
environment; while they might have timber frames, the walls were hessian bags washed with lime but few had any access to water, so they were, like most of the rest of the area, unsewered and unserviced with any sanitary collection. ${ }^{33}$ All of these camped families would have hunted small game and birds along the shores and harvested fish, prawns and oysters from the river.

There were unemployment relief projects in the area too during the Depression, referred to ruefully as 'The Susso', and these included building sections of Henry Lawson Drive (near Georges Hall, Milperra, East Hills and Picnic Point) and less practical sandstone 'Oatley Castle' inside Oatley Park, used, at least for a time, as a kiosk. On the southern side of the river, in 1932, the Reverend Robert Hammond set up an Anglican relief project, Hammondville, just upstream from Voyager Point, offering small blocks to unemployed Christian workmen who could demonstrate their sobriety. Given the sandy and saline soil there, it was unlikely to offer rewarding farming, but the blocks were taken up by some. ${ }^{34}$ (It persists today as an Anglican Church-owned retirement village.) Locals would invariably have been employed on all the heavy work of these relief projects, much of it, like the eccentric Oatley Castle, frustratingly impractical, thus further influencing attitudes to the Georges River.

\section{The More-than-Human World}

There were environmental effects from all these low key uses but these were not striking in the later nineteenth and early twentieth centuries. There was evidence of a very limited mangrove presence in the downstream estuarine regions in the reports of the early British botanist Joseph Banks in 1770. It was the non-botanist, James Cook, who noted mangroves at 'the head' of Botany Bay in 1770, but Banks made no mention of them. Hunter noted extensive mangroves in the Hawkesbury but was silent about any mangroves on the Georges River or Botany Bay shores even though he was camped there for weeks in $1788 .{ }^{35}$

\footnotetext{
33 Ibid., 98-104.

34 Lake, 'Hammondville'.

35 Australian Botanic Garden, 'Banks and Solander Species List', accessed 11 October 2020, www.australianbotanicgarden.com.au/science/the-botany-of-botany-bay/plants/banks-and-solanderspecies-list; Hunter, An Historical Journal.
} 
When observers in the later nineteenth and twentieth centuries saw mangroves expanding, they often assumed that mangroves must have been abundant at the time of colonisation but had been depleted by early colonisers. One reason for this assumed depletion was the very early use of mangroves or saltmarsh for soap making, which was mentioned in a number of secondary sources. However, the amounts of estuarine vegetation that were harvested were not recorded; nor is it known whether the source was trees such as Avicennia marina or some varieties of saltmarsh. In fact, the most frequently cited article, Juliet Bird's 1978 study, is not based on evidence from Sydney but rather from Westernport Bay in Victoria. ${ }^{36}$ Soap manufacturing around Sydney had petered out by $1850 .{ }^{37}$ However, even if more mangroves had been used in the manufacture of soap than the evidence suggests, there was little regrowth; most documentary sources from the later nineteenth century and most art and photographic sources from the nineteenth and early twentieth centuries suggest there were few mangroves in the sheltered estuarine bays along the lower Georges River. While not definitive, this is consistent with Lynne McLoughlin's studies of the Lane Cove River in Sydney's north and the Parramatta River in the west. She dates the expansion of mangroves there to around the $1880 \mathrm{~s}^{38}$

Another use, although much later in the nineteenth century, was that of oyster farmers who used mangrove wood in stands to attract attachment by oyster spawn (or spat) as it drifted through the waters. Yet the Georges River mangroves were depleted already by the turn of the century. Instead of local mangrove stands, oyster farmers who had added leases on the coasts north or south of Sydney would gather mangroves - like the red mangroves of Minnamurra remembered by Laurie Derwent - to be used for catching spat. By 1950, mangroves were unavailable and instead sawn hardwood, tarred to avoid rot, was being used by the industry, generating still further environmental debates. ${ }^{39}$

Another source of information about mangroves arose because observers were aware of the increased siltation of creeks and rivers because of upstream clearing for agriculture. Where they saw mangrove growth, they assumed the vegetation was expanding opportunistically because the new accumulations of silt were making 'islands'. This was the source

36 Bird, 'The Nineteenth-Century Soap Industry'.

37 Ibid., 40.

38 McLoughlin, The Middle Lane Cove River; McLoughlin, 'Mangroves and Grass Swamps'.

39 Derwent, interview. 
of reports such as that in the Sydney Morning Herald of 1885, which noted that a recent government inspection party on the lower Cooks River had found an 'island' of mangroves, which had appeared over the previous 16 years. ${ }^{40}$ Only with evidence emerging from WWII was this assumption of opportunistic expansion (i.e. whenever a silt bed collected) shown to be inadequate.

This evidence came as a result of rising anxieties during the interwar years that led the Royal Australian Air Force (RAAF) to develop its capacity to make use of photography. From 1930 the RAAF began to take annual aerial photographs in strips and in very high resolution, covering the whole of the Australian continent. These photographs confirm that the expansion on the middle reaches of the Georges River estuary may have been a little later than on the lower Cooks River. Comparisons of Georges River photographs from 1930 to the 1980s demonstrate few mangroves present in 1930 but substantial mangrove expansion in later decades. The mangrove expansion at Oatley Bay was landwards only, at the expense of the saltmarsh. But in Salt Pan Creek, mangroves also expanded into the creek. Silt had accumulated as mud flats from clearing for agriculture and timber upstream around Bankstown, but the mangroves had not expanded simply because the mudflats came into being. In fact, many mudflats had stood bare for decades, as can be seen in photographs of the US Army Hospital at Herne Bay taken in $1944 .{ }^{41}$ In the first decade from 1930, any mangrove expansion seems to have gone largely unnoticed, and, where it was noticed, it added to the approval of council work that uprooted mangroves to 'reclaim' riverbanks for parkland.

But, after WWII, the mangrove expansion began to attract attention.

40 'The Cooks River Mud Flats', Sydney Morning Herald, cited in Tyrrell, River Dreams, 87.

41 Haworth, 'Bush Tracks and Bush Blocks'; Haworth, 'Changes in Mangrove/Salt Marsh Distribution'; Canterbury and District Historical Society, photograph, 'I Grew Up in Mortdale', Facebook, accessed 5 May 2020, @igrewupinmortdale2223. 

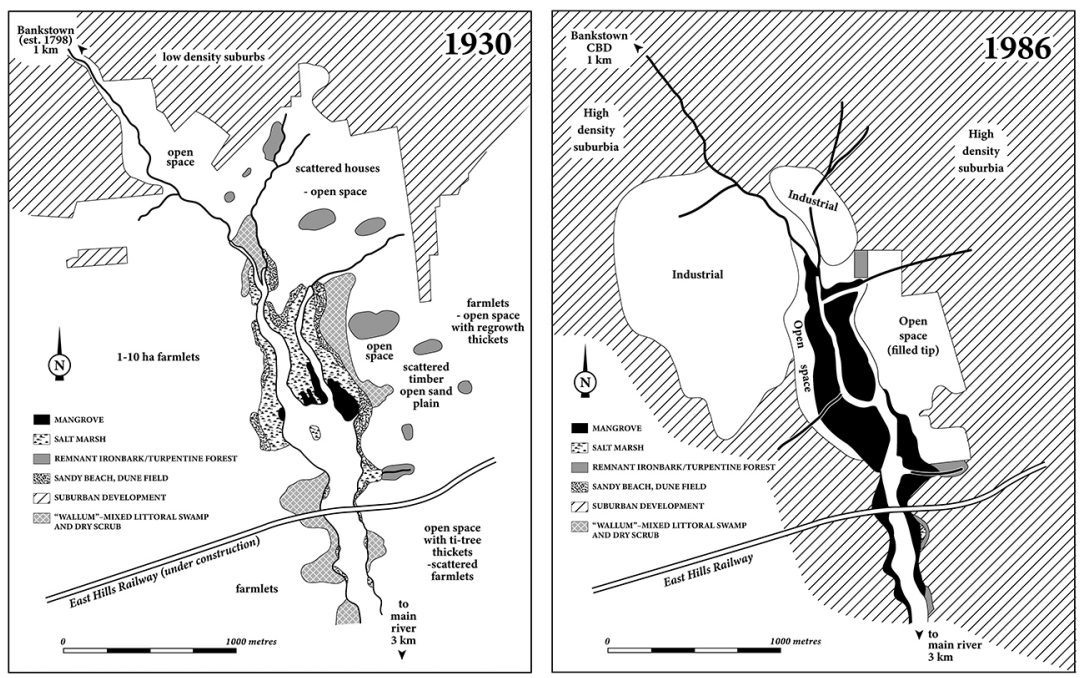

Map 2.3: Mangrove expansion on Salt Pan Creek, 1930-86.

These maps, derived from RAAF aerial photographs, indicate the areas where siltation had been occurring from agriculture and urbanisation for decades before 1930, creating islands, on some of which saltmarsh was growing. Despite this long period of siltation, mangroves had not expanded onto these silt flats or shallow creek areas. Between 1930 and 1986, however, mangrove expansion occurred, leading to the rapid colonisation of all the exposed islands and much of the shallow, silted bed by mangroves. Diagrams redrawn from Goodall, 'Frankenstein, Triffids and Mangroves', based on drawings in Haworth, 'Changes in Mangrove/Salt Marsh Distribution'. See Chapters 10 and 11, this volume. Cartography: Sharon Harrup. 
This text is taken from Georges River Blues: Swamps, Mangroves and Resident Action, 1945-1980, by Heather Goodall, published 2022, The Australian National University, Canberra, Australia.

doi.org/10.22459/GRB.2021.02 